\title{
Has infliximab influenced the course and prognosis of acute severe ulcerative colitis?
}

This article was published in the following Dove Press journal:

Biologics: Targets and Therapy

\author{
Angelo Viscido' \\ Claudio Papi ${ }^{2}$ \\ Giovanni Latella' \\ Giuseppe Frieri' \\ 'Department of Life, Health and \\ Environmental Sciences, University of \\ L'Aquila, L'Aquila, Italy; ${ }^{2}$ IBD Unit, \\ S. Filippo Neri Hospital, Rome, Italy
}

Correspondence: Angelo Viscido Department of Life, Health and Environmental Sciences, University of L'Aquila, Piazzale Salvatore Tommasi I, L'Aquila 67100, Italy

Tel +390862434746

Email angelo.viscido@univaq.it

\begin{abstract}
Ulcerative colitis (UC) still has no definitive cure since its etiology remains unclear. In recent years, considerable progress has been made with regard to our knowledge of the pathogenesis of UC. Advances in biotechnology have led to the development of biologic therapies which selectively target single key mediators or receptors involved in the pathogenesis of the disease - ie, tumor necrosis factor (TNF)- $\alpha$, integrin, interleukins 12/23. Biologic therapies caused a revolution in the treatment of UC, providing specific options for patients refractory to conventional treatment. In recent years, antibodies anti-TNF $\alpha$ and antiintegrin have shown efficacy in improving the course and prognosis of ambulatory patients with moderate-to-severe UC. Nevertheless, whether biologics have brought so many benefits also for hospitalized patients with acute severe UC is still debated. Acute severe UC is a potentially life-threatening condition that affects up to $25 \%$ of patients during the course of their disease. It requires hospital admission due to the risk of complications and death, and it can necessitate urgent colectomy. Major adverse outcomes of acute severe UC are mortality and colectomy. The aim of this systematic review of the literature was to analyze the impact of biologics, in particular infliximab, on the course and prognosis of acute severe UC. Mortality and colectomy rates were considered as outcome measures.
\end{abstract}

Keywords: ulcerative colitis, acute severe ulcerative colitis, mortality, colectomy, biologic therapy, infliximab

\section{Introduction}

Ulcerative colitis (UC) is an idiopathic inflammatory bowel disease that generally begins in young adulthood and lasts a lifetime with a chronic relapsing course. ${ }^{1}$ The incidence is increasing worldwide, while a definitive cure does not yet exist. Although the exact etiology of UC remains unknown, the pathogenesis of the inflammatory lesions appears to be due to a dysregulation of the gut immune system. Inflammation of the colonic mucosa is responsible for signs, symptoms, course, and complications of UC. ${ }^{1-3}$

The clinical course of UC is intermittent, with flares that alternate with periods of remission, being the length of remission quite irregular. ${ }^{2-4} \mathrm{UC}$, usually, is mildly active, but it can be life-threatening during acute severe attacks because of colonic and systemic complications. ${ }^{4-10}$

Acute severe colitis is a medical emergency that affects about $25 \%$ of patients with UC during their life, often at the time of disease onset. ${ }^{4}$ It requires hospitalization due to the risk of complications and death. ${ }^{5-10}$ Management of acute severe colitis has always presented the most difficult challenge in the therapy of UC. ${ }^{11,12}$ At the beginning of the 1900 s, before the introduction of effective therapies, severe disease was the major cause of death as it was reported that mortality within the first year after acute UC onset 
was very high, up to $75 \% .{ }^{13}$ In recent years, mortality rates of patients with acute severe UC have dropped to less than $1 \%$ after the implementation of intravenous (iv) steroids, rescue therapy, and timely surgery. ${ }^{14-18}$ Nevertheless, $20-30 \%$ of patients with acute severe UC require colectomy. ${ }^{19}$

The recent introduction of biologic therapies caused a basic change in the management of patients with UC giving hope for a new shift in the course and prognosis of the disease, particularly in acute severe colitis. ${ }^{20-22}$ Antibodies anti-tumor necrosis factor (TNF)- $\alpha$ (infliximab, adalimumab, golimumab) and anti-integrins (vedolizumab) are currently recommended as options for treating moderate-to-severe active UC in patients who had responded inadequately to conventional therapy, or who cannot tolerate or have medical contraindications for, such therapies. ${ }^{23,24}$ A systematic review of the literature demonstrated that anti-TNF $\alpha$ biologics are able to reduce the need for hospitalization and surgery in patients with moderate-to-severe UC. ${ }^{21}$

In the setting of acute severe UC, infliximab is the only biologic that was specifically tested in steroidrefractory patients. Currently, it represents the most widely used rescue therapy in patients with acute severe colitis refractory to iv steroids. ${ }^{8-10}$ However, the impact of infliximab on the course and prognosis of acute severe UC is still a topic of argument. ${ }^{5-10}$

The present review was conducted to evaluate whether infliximab has changed the course and prognosis of patients with acute severe UC. The outcomes considered for this analysis were mortality and surgery, with a focus on long-term follow-up.

\section{Search strategy}

We led a systematic literature search in order to identify studies investigating the course and prognosis of patients with acute severe UC. All the studies evaluating surgery and/or mortality as outcome measures were taken. The electronic search was performed in PubMed up to December 2018 using the following keywords: "acute severe ulcerative colitis", "acute severe colitis", "refractory ulcerative colitis", "steroid-refractory ulcerative colitis", "mortality", "colectomy". In addition, the reference lists of the selected articles were reviewed to identify additional relevant studies.

\section{Acute severe UC: course and prognosis}

Since the first description in 1859 by Wilks, ${ }^{25} \mathrm{UC}$ has remained for many decades without any effective treatment. ${ }^{13,26-34}$ Reports from that period show that UC, although relatively rare, was a serious illness, difficult to treat, and lasting a lifetime whether not responsible for premature death. Mortality was very high. ${ }^{11,12}$ Table 1 shows the mortality rates of UC in some hospital series published in the early $1900 \mathrm{~s} .{ }^{13,26-34}$ Overall mortality ranged from $20 \%$ to $55 \%$ of the patients with UC. The mortality during the first year after acute UC onset was much higher, up to $75 \%$ of the patients.

Hence, a cure to reduce mortality in acute severe UC began the major objective for all the doctors. ${ }^{35}$

\section{The steroid era}

The first drug really effective in the treatment of UC was sulphasalazine, introduced in the $1940 \mathrm{~s},{ }^{36}$ but the true

Table I Mortality rates of ulcerative colitis (UC) in some hospital series published in the early 1900s. Overall mortality was from $20 \%$ to $55 \%$ of the patients with UC. The mortality during the first year after acute UC onset was up to $75 \%$. Reported studies were made in tertiary-care referral centers, most likely including only the more severe cases of UC.

\begin{tabular}{|c|c|c|c|c|c|}
\hline Reference & Hospital & Period & Patients (n) & $\begin{array}{l}\text { Mortality: } \\
\text { overall (\%) }\end{array}$ & $\begin{array}{l}\text { Mortality: } \\
\text { I }^{\text {st }} \text {-year after acute onset }(\%)\end{array}$ \\
\hline Allchin $1909^{27}$ & London & $1883-1909$ & 177 & 56 & $\mathrm{nr}$ \\
\hline Hawkins $1909^{28}$ & London & Up to 1909 & 85 & 48 & $\mathrm{nr}$ \\
\hline Marnham $1937^{30}$ & London & $1925-1929$ & 214 & 49 & 32 \\
\hline Hardy $1933^{13}$ & Birmingham & $1920-1932$ & 95 & 33 & 75 \\
\hline Vaizey $1940^{31}$ & London & $1931-1937$ & 81 & 36 & 18 \\
\hline Wheelock $1955^{32}$ & Boston & $1915-1943$ & 483 & 55 & 20 \\
\hline Kirsner $1948^{33}$ & Chicago & Up to 1947 & 100 & 14 & 60 \\
\hline Rice-Oxley $1950^{34}$ & Oxford & 1938-1948 & 72 & 31 & 22 \\
\hline
\end{tabular}

Abbreviation: $\mathrm{nr}$, not reported. 


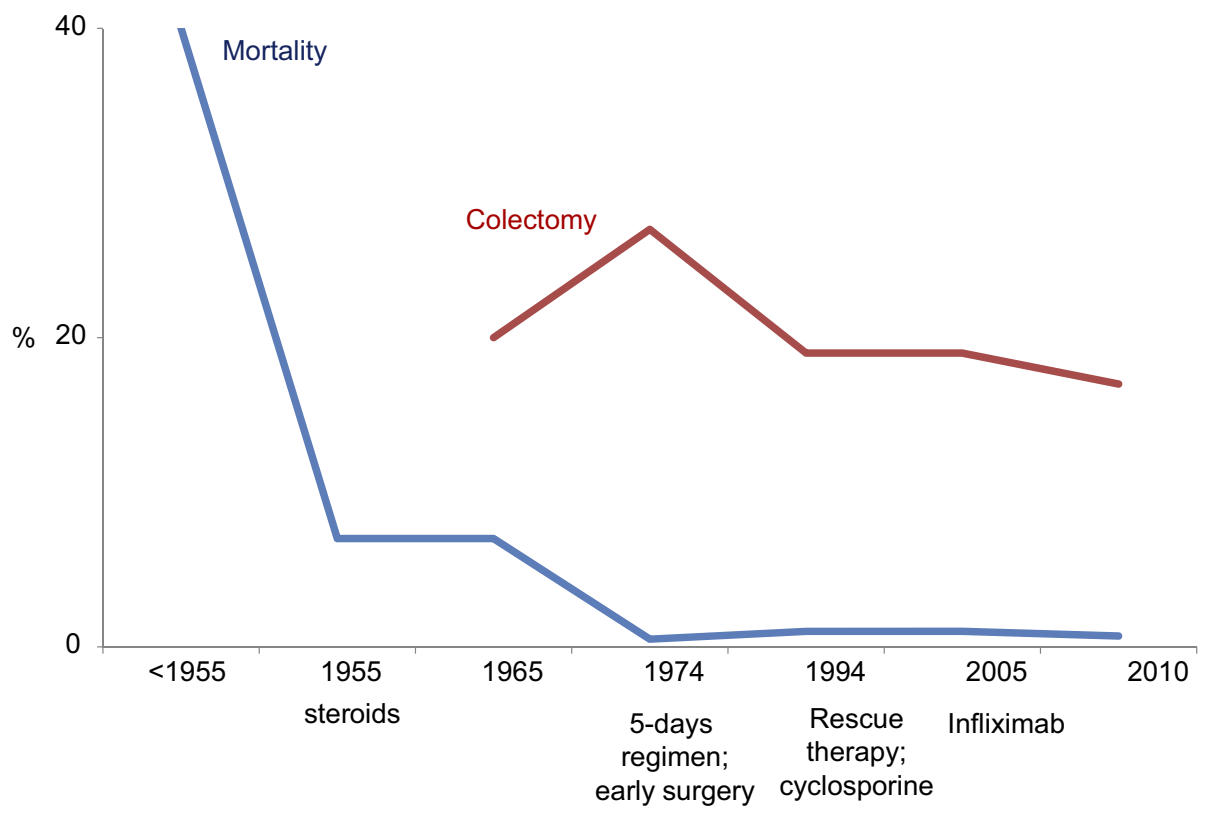

Figure I Trends in mortality and colectomy rate in different time periods. Mortality in acute severe ulcerative colitis (UC) in the pre-steroid era was up to $75 \%$. ${ }^{12,13}$ Steroids (1955) reduced mortality to $7 \%{ }^{14}$ Early surgery (1974) definitively reduced deaths to about $1 \% .{ }^{17}$ The mortality rate of acute severe UC has remained unchanged at about $1 \%$ since $1974 .{ }^{40}$ The need for colectomy was reduced by the introduction of rescue therapies. ${ }^{44,52}$.

revolution in the treatment of severe disease was the introduction of steroids (Figure 1). ${ }^{11}$ In 1955, Truelove and Witts reported the results of the first controlled trial of cortisone in the treatment of UC, in which steroids significantly reduced the mortality of patients with severe UC $(7 \%$ in the cortisone group vs $24 \%$ in the placebo group). ${ }^{14}$ In the same year, Avery Jones confirmed with another placebo-controlled study that cortisone significantly reduces the mortality of patients with acute severe UC $(4.6 \%$ in the cortisone group vs $9.9 \%$ in the control group). ${ }^{15}$ In both studies, patients presenting with the most severe attacks of UC were not included.

In subsequent years, surgeons realized that surgery could have played a role in patients with severe UC who fail to respond to cortisone. ${ }^{37-39}$ In 1967, Goligher reported the results of a retrospective analysis in which early surgery was associated with reduced mortality rates in patients with acute severe UC refractory to steroids (mortality before 1963: 11.3\%; mortality after the institution of early surgery in 1964: $1.3 \%) .{ }^{16}$ Surgery consisted of proctocolectomy with ileostomy.

Prognosis of patients with acute severe UC definitively improved after 1974, the date on which Truelove and Jewell reported the results of their uncontrolled experience in severe attacks of UC with a 5-day intensive program based on intravenous steroids and early surgery, recording a further decrease in the mortality rate to about $1 \%{ }^{17}$ This program, known as the Oxford regimen, consisted of stopping oral alimentation except for water, intravenous administration of $3 \mathrm{~L}$ of fluid per day with potassium and vitamins $\mathrm{B}$ and $\mathrm{C}$, blood transfusions, prednisolone $60 \mathrm{mg}$ (or hydrocortisone $400 \mathrm{mg}$ ), tetracycline $1 \mathrm{~g}$; hydrocortisone $100 \mathrm{mg}$ was administered via the rectum. If no definite improvement was observed after 5 days of intensive treatment surgery was recommended. ${ }^{17}$

The Oxford regimen proved to be a strong indication of urgent colectomy. Surgery had become a life-saving procedure for patients with severe UC unresponsive to steroids.

- Interestingly, the mortality rate of acute severe UC has remained unchanged at about $1 \%$ since $1974 .{ }^{40}$ Neither cyclosporine nor biologics resulted able to change mortality rates.

\section{Rescue therapy}

Once reduced the mortality for acute severe UC to about $1 \%$, the new target of therapy in severe attacks became to avoid colectomy. Nevertheless, colectomy rates remained unchanged at about $30 \%$ of patients with acute severe UC for many years. ${ }^{19,40}$

Colectomy is life-saving in patients with acute severe UC unresponsive to steroids, but it is burdened by 
operative mortality, complications, and disability. ${ }^{41,42}$ Currently, early colectomy still determines a mortality rate of $5 \%$ and a complication rate of $64 \%{ }^{43}$

Treatment put in place to avoid surgery after failure of iv steroids is commonly defined as "rescue therapy".

In 1994, Lichtiger reported the results of a randomized controlled trial (RCT) in which iv cyclosporine at a daily dosage of $4 \mathrm{mg} / \mathrm{kg}$ was significantly more beneficial than placebo as rescue therapy in reducing the need of colectomy in patients with severe UC who had failed to respond to iv steroids (colectomy rates: $18 \%$ in the cyclosporine group respect to $44 \%$ in the placebo group). ${ }^{44}$ Subsequently, an RCT comparing 4 vs $2 \mathrm{mg} / \mathrm{kg}$ daily iv cyclosporine demonstrated that $2 \mathrm{mg} / \mathrm{kg}$ is the optimal cyclosporine dose in the treatment of severe attacks of UC. ${ }^{45}$

Although cyclosporine is quickly effective as rescue therapy in the short term, ${ }^{44-46}$ its efficacy disappears in the long-term follow-up. ${ }^{47,48}$ Systematic reviews of the literature on severe UC indicate that evidence of long-term efficacy of cyclosporine is weak and that cyclosporine does not avoid, but only delay, the overall need for colectomy. ${ }^{48-50}$ On the basis of these observations, the systematic use of cyclosporine in severe UC was the topic of a long debate.

Cyclosporine represented the mainstay of rescue therapy in acute severe UC until the advent of biologics, but its use significantly decreased after that. ${ }^{51}$

- Summarizing, cyclosporine reduces the need for colectomy in the short-term follow-up, but it has no effect on colectomy rates in the long-term follow-up.

\section{The biologic era of rescue therapy}

The introduction of biologic therapies caused a revolution in the management of $\mathrm{UC} .{ }^{20}$ A large number of patients with UC are currently treated with biologics. Anti-TNF $\alpha$ antibodies (infliximab, adalimumab, and golimumab) and anti$\alpha 4 \beta 7$-integrin antibodies (vedolizumab), are effective at inducing and maintaining remission in ambulatory patients with moderate to severe UC. ${ }^{23,24}$ Instead, in hospitalized patients with acute severe UC, infliximab is the only biologic that was specifically tested as rescue therapy. ${ }^{52}$

\section{Infliximab}

Table 2 shows the results of the controlled trials of infliximab in acute severe UC. ${ }^{52-60}$ A pilot RCT published in 2001 by Sands reported that infliximab was superior to placebo at avoiding colectomy in patients with severe UC refractory to steroid therapy. Colectomy rates were $50 \%$ in the infliximab group respect to $100 \%$ in the placebo group. ${ }^{53}$ Subsequently, in 2004, another pilot RCT demonstrated that infliximab alone and steroids are equally effective in the treatment of patients with acute severe UC who were not steroid-refractory, indicating that infliximab may be an alternative to steroids in patients who cannot take them. ${ }^{54}$ In 2005, Jarnerot reported the results of an RCT for the treatment of patients with severe UC refractory to steroids, in which a "single dose" of infliximab $(5 \mathrm{mg} / \mathrm{kg})$ was significantly superior to placebo as rescue therapy at avoiding colectomy. At 3 months of follow-up, colectomy rates were $29 \%$ in the infliximab group respect to $67 \%$ in controls. ${ }^{52}$ The difference was still significant in the long term as at 3 years of follow-up the colectomy rates were $50 \%$ in the infliximab group respect to $76 \%$ in the placebo group. ${ }^{55}$ The main advantage of infliximab treatment occurred during the first 3 months. At 3 months of followup, $40 \%$ of patients who had avoided colectomy after infliximab showed endoscopic mucosal healing (defined as a Mayo endoscopic sub-score of 0 ). None of the patients $(0 \%)$ with mucosal healing at 3 months underwent surgery during the 3-year follow-up compared with 50\% of the patients without endoscopic remission. There was no mortality. ${ }^{55}$

Lastly, infliximab was directly compared to cyclosporine. The first study (ie, CYSIF) was performed by the French group GETAID with a design based on the assumption that cyclosporine was superior to infliximab in patients with severe UC refractory to intravenous steroids. The study included 115 patients who were randomly assigned to receive cyclosporine or infliximab. At 3 months of follow-up, cyclosporine and infliximab had similar efficacy in avoiding urgent colectomy (colectomy rates: $17 \%$ after cyclosporine and $21 \%$ after infliximab). ${ }^{57}$ Recently, the long-term outcomes of this study were reported. After a median follow-up of 5 years, colectomy rates continued to be similar in the two groups of patients, those initially treated with cyclosporine and those with infliximab (39\% vs $35 \%$, respectively) ${ }^{58}$ It is noteworthy that in that study, nearly half of the patients initially treated with cyclosporine needed to switch over to infliximab within the first year. The subsequent use of infliximab could justify the more favorable long-term outcome after cyclosporine treatment observed in this study with respect to previous data. Another study (ie, CONSTRUCT) was conducted in the UK and included 270 patients with steroid-resistant acute severe UC who were randomly assigned to receive infliximab or cyclosporine. At a median 
Table 2 Controlled studies evaluating the efficacy of infliximab in the treatment of acute severe UC. Studies compared infliximab to placebo, prednisolone, or cyclosporine. Studies were retrieved by a systematic review of PubMed and the reference list of the selected papers.

\begin{tabular}{|c|c|c|c|c|c|c|c|c|}
\hline \multirow[t]{2}{*}{ Reference } & \multirow[t]{2}{*}{ Control } & \multirow{2}{*}{$\begin{array}{l}\text { Pts number } \\
\text { (infiximab vs } \\
\text { controls) }\end{array}$} & \multirow[t]{2}{*}{ Infusions } & \multirow{2}{*}{$\begin{array}{l}\text { Dose } \\
(\mathrm{mg} / \mathrm{kg})\end{array}$} & \multirow[t]{2}{*}{ Follow-up } & \multicolumn{3}{|l|}{ Surgery (\%) } \\
\hline & & & & & & Infliximab & controls & $p$ \\
\hline Sands $2001^{53}$ & Placebo & $\begin{array}{l}\text { II } \\
\text { (8 vs 3) }\end{array}$ & I & $5 ; 10 ; 20$ & $\begin{array}{l}2 \text { weeks } \\
3 \text { months }\end{array}$ & $\begin{array}{l}12.5 \\
50\end{array}$ & $\begin{array}{l}100 \\
100\end{array}$ & $<0.05$ \\
\hline Ochsenkuhn $2004^{54}$ & Prednisolone & $\begin{array}{l}13 \\
\text { (6 vs } 7)\end{array}$ & 3 & 5 & 3 weeks & 0 & 0 & ns \\
\hline $\begin{array}{l}\text { Jarnerot } 2005^{52} \\
\text { Gustavsson } 2010^{55}\end{array}$ & Placebo & $\begin{array}{l}45 \\
(24 \text { vs } 2 I)\end{array}$ & I & $4 ; 5$ & $\begin{array}{l}3 \text { months } \\
3 \text { years }\end{array}$ & $\begin{array}{l}29 \\
50\end{array}$ & $\begin{array}{l}67 \\
76\end{array}$ & $<0.05$ \\
\hline Bossa $2009^{56}$ & Cyclosporine & $\begin{array}{l}21 \\
\text { (14 vs } 7)\end{array}$ & 3 & 5 & I month & 43 & 43 & ns \\
\hline $\begin{array}{l}\text { Laharie } 2012^{57} \\
\text { Laharie } 2018^{58}\end{array}$ & Cyclosporine & $\begin{array}{l}115 \\
(58 \text { vs } 57)\end{array}$ & $3^{\wedge}$ & 5 & $\begin{array}{l}3 \text { months } \\
5 \text { years }\end{array}$ & $\begin{array}{l}21 \\
35\end{array}$ & $\begin{array}{l}17 \\
39 *\end{array}$ & ns \\
\hline Williams $2016^{59}$ & Cyclosporine & $\begin{array}{l}270 \\
\text { (I35 vs I35) }\end{array}$ & 3 & 5 & 2 years & 41 & 48 & ns \\
\hline Croft $2013^{60}$ & Cyclosporine $* *$ & $\begin{array}{l}83 \\
(38 \text { vs } 45)\end{array}$ & I & 5 & $\begin{array}{l}3 \text { months } \\
\text { I year }\end{array}$ & $\begin{array}{l}24 \\
35\end{array}$ & $\begin{array}{l}47 \\
58\end{array}$ & $<0.05$ \\
\hline
\end{tabular}

Notes: *Approximately $50 \%$ of the patients who avoided colectomy at 3 months with cyclosporine required switching to infliximab to maintain remission in the longterm follow-up. **Not randomized study. p: significance.

Abbreviation: Pts, patients.

follow-up of 2 years, colectomy rates were similar between infliximab and cyclosporine group $(41 \%$ vs $48 \%$, respectively). ${ }^{59}$

Systematic reviews of both randomized and nonrandomized studies comparing infliximab and cyclosporine as rescue therapy in patients with severe UC refractory to steroids demonstrate that infliximab is associated with lower risk of colectomy at 12 months, respect to cyclosporine. ${ }^{50}$

- Summarizing, infliximab is similar to cyclosporine at reducing the need for colectomy in the short-term follow-up, but it demonstrates higher efficacy in the long-term follow-up. Interestingly, recent populationbased cohort studies demonstrate a significant reduction of colectomy rates in the era of biologics. ${ }^{61-63}$

\section{Optimal use of infliximab}

Optimal use of infliximab in acute severe UC is still to be defined. Currently, the conventional 3-doses induction regimen (infliximab $5 \mathrm{mg} / \mathrm{kg}$ given at $0,2,6$ weeks) is used in place of the single induction dose. ${ }^{64}$ Many recent observations indicate that an intensified dosing induction regimen, either through increased infliximab doses $(>5 \mathrm{mg} / \mathrm{kg})$ and/or an accelerated dosing schedule, could improve the efficacy of infliximab in decreasing the need of colectomy. ${ }^{65,66}$

A retrospective study by Gibson published in 2015 reported a single-center experience of 50 patients treated with infliximab due to acute severe UC refractory to steroids. A total of 35 patients received standard 6-week infliximab induction and 15 patients received an accelerated infliximab induction regimen ( 3 doses of infliximab over 2 weeks). Both groups kept on maintenance therapy every 8 weeks. At 3 months of followup, colectomy rates were $40 \%$ in the conventional dosing group and $6.7 \%$ in the accelerated regimen. ${ }^{65}$

A recent meta-analysis of published literature did not detect that an accelerated infliximab induction was associated with better outcomes, in particular, reduced need for colectomy, when compared to standard induction dosing. Interestingly, among those receiving accelerated induction, those who received $10 \mathrm{mg} / \mathrm{kg}$ as their first infliximab dose had a trend toward a reduced risk of colectomy when compared to simply shorten the interval between $5 \mathrm{mg} / \mathrm{kg}$ doses. ${ }^{67}$ Results of an ongoing comparative RCT of different infliximab induction strategies for acute severe UC (PREDICT-UC study) will probably resolve the question in the next future. ${ }^{68}$ 
The use of intensified dosing regimens in acute severe UC by means of higher doses $(10 \mathrm{mg} / \mathrm{kg})$ and/or accelerated induction regimens (ie, given at $0,1,2$ weeks) is in keeping with infliximab pharmacokinetics data. Pharmacokinetic studies suggest that acute severe inflammation could require a higher dose of infliximab to obtain adequate therapeutic levels. This could be possibly due to a higher inflammatory activity and/or increased infliximab clearance via fecal loss. ${ }^{69}$ Higher inflammatory activity results in higher levels of TNF $\alpha$ to be neutralized by infliximab. ${ }^{70}$ Severe colonic inflammation allows efflux of infliximab into the colonic lumen and fecal loss of the drug. ${ }^{71}$ Increased clearance of infliximab leads to low drug concentrations which may enhance immunogenicity and facilitate the formation of anti-drug antibodies. ${ }^{69,70}$

The demonstration that infliximab trough levels are lower in patients with acute severe UC refractory to iv steroids respect to out-patients with moderately severe UC undergoing the same conventional infliximab induction regimen validates this hypothesis. ${ }^{72}$

It has been observed that serum albumin is a powerful predictive factor of infliximab clearance in patients with acute severe UC. The CRP/albumin ratio is a powerful predictor of colectomy, and it has been suggested as a tool to identify high-risk patients who necessitate accelerated induction regimen. ${ }^{73,74}$

\section{Future directions}

"Second-line rescue therapy" or "sequential therapy" following the failure of rescue therapy consists of giving cyclosporine first, followed by an anti-TNF $\alpha$ treatment, and vice versa. Current guidelines recommend that only a single attempt at rescue therapy with cyclosporine or infliximab should be considered before referral for colectomy. ${ }^{23}$ Due to the high risk of adverse events, sequential therapy can be considered only in specialist referral centers in highly selected cases, after careful discussion between the patient, gastroenterologist, and the surgeon.

Biosimilars to infliximab are replacing all over the world the originator. Two studies evaluating the biosimilar CT-P13 in patients with acute severe UC reported no differences respect to the originator infliximab. ${ }^{75,76}$

A valid alternative to cyclosporine or infliximab as rescue therapy in patients with acute severe UC is still lacking. ${ }^{77-79}$ Antibodies toward interleukins (ILs)-12/23 (ustekinumab) and tofacitinib (a not biologic small molecule inhibiting Janus Kinase) have been used in small series of patients with severe UC but it is too early to hypothesize their use. ${ }^{80,81}$

\section{Conclusive remarks}

- Infliximab did not influence the mortality rate of acute severe UC. The mortality rate of acute severe UC has remained unchanged at about 1\% since 1974.

- Infliximab and cyclosporine are equally effective as rescue therapy to reduce colectomy rates in the shortterm follow-up.

- Infliximab is superior to cyclosporine at avoiding colectomy in the long-term follow-up. It has been observed that switching over to infliximab contributes to maintaining colectomy-free remission in patients who initially avoided surgery with cyclosporine.

- The efficacy of infliximab in acute severe UC will probably increase in the next future due to optimization of induction regimen.

Summarizing, infliximab seems to have improved the course and prognosis of acute severe UC by improving the long-term outcomes of rescue therapy. Further studies are needed to confirm these preliminary observations.

\section{Disclosure}

Claudio Papi reports personal fees from Abbvie, Takeda, MSD, Chiesi, Sofar, Janssen Cilag, and Ferring, outside the submitted work. The other authors report no conflicts of interest in this work.

\section{References}

1. Ungaro R, Mehandru S, Allen PB, Peyrin-Biroulet L, Colombel JF. Ulcerative colitis. Lancet. 2017;389(10080):1756-1770. doi:10.1016/ S0140-6736(16)32126-2

2. Cosnes J, Gower-Rousseau C, Seksik P, Cortot A. Epidemiology and natural history of inflammatory bowel diseases. Gastroenterology. 2011;140(6):1785-1794. doi:10.1053/j.gastro.2011.01.055

3. Fumery M, Singh S, Dulai PS, Gower-Rousseau C, Peyrin-Biroulet L, Sandborn WJ. Natural history of adult ulcerative colitis in population-based cohorts: a systematic review. Clin Gastroenterol Hepatol. 2018;16(3):343-356. doi:10.1016/j.cgh.2017.06.016

4. Burisch J, Katsanos KH, Christodoulou DK, et al. Epi-IBD group. Natural disease course of ulcerative colitis during the first five years of follow-up in a European population-based inception cohort-an Epi-IBD study. J Crohns Colitis. 2018. doi:10.1093/ecco-jcc/jjy154

5. Caprilli R, Viscido A, Latella G. Current management of severe ulcerative colitis. Nat Clin Pract Gastroenterol Hepatol. 2007;4 (2):92-101. doi:10.1038/ncpgasthep0687

6. Seah D, De Cruz P. Review article: the practical management of acute severe ulcerative colitis. Aliment Pharmacol Ther. 2016;43 (4):482-513. doi:10.1111/apt.13491 
7. Hindryckx P, Jairath V, D'Haens G. Acute severe ulcerative colitis: from pathophysiology to clinical management. Nat Rev Gastroenterol Hepatol. 2016;13(11):654-664. doi:10.1038/ nrgastro.2016.116

8. Gisbert JP, Chaparro M. Acute severe ulcerative colitis: state of the art treatment. Best Pract Res Clin Gastroenterol. 2018;32-33:59-69. doi:10.1016/j.bpg.2018.05.007

9. Whaley KG, Rosen MJ. Contemporary medical management of acute severe ulcerative colitis. Inflamm Bowel Dis. 2018. doi:10.1093/ibd/ izy208

10. Dulai PS, Jairath V. Acute severe ulcerative colitis: latest evidence and therapeutic implications. Ther Adv Chronic Dis. 2018;9 (2):65-72. doi:10.1177/2040622317742095

11. Cullinan ER. Ulcerative colitis: clinical aspects. $\mathrm{Br}$ Med J. 1938;2 (4069):1351-1356.

12. Texter EC. The natural history of ulcerative colitis. J Chronic Dis. 1957;5(3):347-369.

13. Hardy TL, Bulmer E. Ulcerative colitis: a survey of ninety-five cases. Br Med J. 1933;2(3800):812-815.

14. Truelove SC, Witts LJ. Cortisone in ulcerative colitis; final report on a therapeutic trial. Br Med J. 1955;2(4947):1041-1048.

15. Jones FA. Ulcerative colitis. Calif Med. 1955;82(2):430-435.

16. Goligher JC, de Dombal FT, Graham NG, Watkinson G. Early surgery in the management of severe ulcerative colitis. $\mathrm{Br}$ Med $\mathrm{J}$ 1967;3(5559):193-195.

17. Truelove SC, Jewell DP. Intensive intravenous regimen for severe attacks of ulcerative colitis. Lancet. 1974;1(7866):1067-1070.

18. Truelove SC, Willoughby CP, Lee EG, Kettlewell MG. Further experience in the treatment of severe attacks of ulcerative colitis Lancet. 1978;2(8099):1086-1088.

19. Turner D, Walsh CM, Steinhart AH, Griffiths AM. Response to corticosteroids in severe ulcerative colitis: a systematic review of the literature and a meta-regression. Clin Gastroenterol Hepatol. 2007;5(1):103-110. doi:10.1016/j.cgh.2006.09.033

20. Rutgeerts P, Sandborn WJ, Feagan BG, et al. Infliximab for induction and maintenance therapy for ulcerative colitis. $N \mathrm{Engl} \mathrm{J} \mathrm{Med.}$ 2005;353(23):2462-2476. doi:10.1056/NEJMoa050516

21. Mao EJ, Hazlewood GS, Kaplan GG, Peyrin-Biroulet L, Ananthakrishnan AN. Systematic review with meta-analysis: comparative efficacy of immunosuppressants and biologics for reducing hospitalization and surgery in Crohn's disease and ulcerative colitis. Aliment Pharmacol Ther. 2017;45(1):3-13. doi:10.1111/apt.13847

22. Cholapranee A, Hazlewood GS, Kaplan GG, Peyrin-Biroulet L, Ananthakrishnan AN. Systematic review with meta-analysis: comparative efficacy of biologics for induction and maintenance of mucosal healing in Crohn's disease and ulcerative colitis controlled trials. Aliment Pharmacol Ther. 2017;45(10):1291-1302. doi:10.1111/ apt. 14030

23. Harbord M, Eliakim R, Bettenworth D, et al. European Crohn's and Colitis Organisation (ECCO). Third European evidence-based consensus on diagnosis and management of ulcerative colitis. Part 2 : current management. J Crohns Colitis. 2017;11(7):769-784. doi:10.1093/ecco-jcc/jjx009

24. National Institute for Health and Care Excellence (NICE). Inducing remission in people with ulcerative colitis. NICE Pathway last updated; 18 January 2018. Available from: http://pathways.nice.org. uk/pathways/ulcerative-colitis

25. Wilks S. Morbid appearances in the intestine of miss bankes.London Med Gaz 1859;2:264. Quoted from: crohn BB. An historic note on ulcerative colitis. Gastroenterology. 1962;42:366-367.

26. Hale White W. Colitis. Lancet. 1895;145(3731):537-538. doi:10.1016/S0140-6736(02)05560-5

27. Allchin WH. A discussion on "Ulcerative Colitis.": introductory address. Proc R Soc Med. 1909;2(Med Sect):59-75.

28. Hawkins HP. An address on the natural history of ulcerative colitis and its bearing on treatment. $\mathrm{Br}$ Med $J$. 1909;1(2517):765-770.
29. McKittrick LS, Miller RH. Idiopathic ulcerative colitis: a review of 149 cases with particular reference to the value of, and indications for surgical treatment. Ann Surg. 1935;102(4):656-673.

30. Bargen JA. The medical management of chronic ulcerative colitis. Proc R Soc Med. 1937;30(4):351-362.

31. Proceedings of the Royal Society of Medicine "Vol. XXXIII page 1 g 637 Section of proctology. President: Lockhart-Mummery JP. Discussion on the surgical treatment of idiopathic ulcerative colitis and its sequelae. (May 8, 1940).

32. Wheelock FC, Warren R. Ulcerative colitis; follow-up studies. $N$ Engl J Med. 1955;252(11):421-425. doi:10.1056/NEJM195503172521102

33. Kirsner JB, Palmer WL, Maimon SN, Ricketts WE. Clinical course of chronic nonspecific ulcerative colitis. J Am Med Assoc. 1948;137 (11):922-928.

34. Rice-Oxley JM, Truelove S. Ulcerative colitis. Course and prognosis. Lancet. 1950;255(6606):663-666. doi:10.1016/S0140-6736(50)90550-2

35. Hurst AF. Treatment of Ulcerative Colitis. Br Med J. 1936;1 (3919):320-321.

36. Svartz N. Salazopyrin, a new sulfanilamide preparation. A. Therapeutic results in rheumatic polyarthritis. B. Therapeutic effects in ulcerative colitis. C. Toxic manifestations in treatment with sulfanilamide preparations. Acta Med Scand. 1942;110:580-598.

37. De Dombal FT, Watts JM, Watkinson G, Goligher JC. The early course and prognosis of ulcerative colitis. Proc R Soc Med. 1965;58 (9):711-713

38. Watts JM, De Dombal FT, Watkinson G, Goligher JC. Early course of ulcerative colitis. Gut. 1966;7(1):16-31.

39. Brooke BN. Total colectomy in one stage for ulcerative colitis. Lancet. 1951;1(6666):1197-1199.

40. Lynch RW, Lowe D, Protheroe A, Driscoll R, Rhodes JM, Arnott ID. Outcomes of rescue therapy in acute severe ulcerative colitis: data from the United Kingdom inflammatory bowel disease audit. Aliment Pharmacol Ther. 2013;38(8):935-945. doi:10.1111/apt.12473

41. Goligher JC, Hoffman DC, de Dombal FT. Surgical treatment of severe attacks of ulcerative colitis, with special reference to the advantages of early operation. Br Med J. 1970;4(5737):703-706.

42. Peyrin-Biroulet L, Germain A, Patel AS, Lindsay JO. Systematic review: outcomes and post-operative complications following colectomy for ulcerative colitis. Aliment Pharmacol Ther. 2016;44 (8):807-816. doi:10.1111/apt.13763

43. Leeds IL, Sundel MH, Gabre-Kidan A, et al. Outcomes for ulcerative colitis with delayed emergency colectomy are worse when controlling for preoperative risk factors. Dis Colon Rectum. 2018. Epub ahead of print. doi:10.1097/DCR.0000000000001276

44. Lichtiger S, Present DH, Kornbluth A, et al. Cyclosporine in severe ulcerative colitis refractory to steroid therapy. $N$ Engl J Med. 1994;330(26):1841-1845. doi:10.1056/NEJM199406303302601

45. Van Assche G, D'Haens G, Noman M, et al. Randomized, double-blind comparison of $4 \mathrm{mg} / \mathrm{kg}$ versus $2 \mathrm{mg} / \mathrm{kg}$ intravenous cyclosporine in severe ulcerative colitis. Gastroenterology. 2003;125(4):1025-1031.

46. D’Haens G, Lemmens L, Geboes K, et al. Intravenous cyclosporine versus intravenous corticosteroids as single therapy for severe attacks of ulcerative colitis. Gastroenterology. 2001;120(6):1323-1329.

47. Moskovitz DN, Van Assche G, Maenhout B, et al. Incidence of colectomy during long-term follow-up after cyclosporine-induced remission of severe ulcerative colitis. Clin Gastroenterol Hepatol. 2006;4(6):760-765. doi:10.1016/j.cgh.2006.04.001

48. Shibolet O, Regushevskaya E, Brezis M, Soares-Weiser K. Cyclosporine A for induction of remission in severe ulcerative colitis. Cochrane Database Syst Rev. 2005;(1):CD004277.

49. Thorne K, Alrubaiy L, Akbari A, Samuel DG, Morrison-Rees S, Roberts SE. Colectomy rates in patients with ulcerative colitis following treatment with infliximab or ciclosporin: a systematic literature review. Eur J Gastroenterol Hepatol. 2016;28(4):369-382. doi:10.1097/MEG.0000000000000568 
50. Narula N, Marshall JK, Colombel JF, et al. Systematic review and meta-analysis: infliximab or cyclosporine as rescue therapy in patients with severe ulcerative colitis refractory to steroids. Am $J$ Gastroenterol. 2016;111(4):477-491. doi:10.1038/ajg.2016.7

51. Royal College of Physicians. UK IBD Audit 2008 (Executive Summary). Prepared by the UK Inflammatory Bowel Disease Audit Steering Group. London: RCP; 2009.

52. Järnerot G, Hertervig E, Friis-Liby I, et al. Infliximab as rescue therapy in severe to moderately severe ulcerative colitis: a randomized, placebo-controlled study. Gastroenterology. 2005;128(7):1805-1811.

53. Sands BE, Tremaine WJ, Sandborn WJ, et al. Infliximab in the treatment of severe, steroid-refractory ulcerative colitis: a pilot study. Inflamm Bowel Dis. 2001;7(2):83-88.

54. Ochsenkühn T, Sackmann M, Göke B. Infliximab for acute, not steroid-refractory ulcerative colitis: a randomized pilot study. Eur $J$ Gastroenterol Hepatol. 2004;16(11):1167-1171.

55. Gustavsson A, Järnerot G, Hertervig E, et al. Clinical trial: colectomy after rescue therapy in ulcerative colitis - 3-year follow-up of the Swedish-Danish controlled infliximab study. Aliment Pharmacol Ther. 2010;32(8):984-989. doi:10.1111/j.1365-2036.2010.04435.x

56. Bossa F, Caruso N, Accadia L, et al. Oral cyclosporin vs infliximab in patients with severe ulcerative colitis refractory to iv steroids. Preliminary data of a controlled, randomized study. J Crohns Colitis. 2009;3(1):S61- P127. doi:10.1016/S1873-9946(09)60154-9

57. Laharie D, Bourreille A, Branche J, et al. Groupe d'Etudes thérapeutiques des affections inflammatoires digestives. Ciclosporin versus infliximab in patients with severe ulcerative colitis refractory to intravenous steroids: a parallel, open-label randomised controlled trial. Lancet. 2012;380 (9857):1909-1915. doi:10.1016/S0140-6736(12)61084-8

58. Laharie D, Bourreille A, Branche J, et al. Groupe d'Etudes thérapeutiques des affections inflammatoires digestives. Long-term outcome of patients with steroid-refractory acute severe UC treated with ciclosporinor infliximab. Gut. 2018;67(2):237-243. doi:10.1136/gutjnl2016-313060

59. Williams JG, Alam MF, Alrubaiy L, et al. Infliximab versus ciclosporin for steroid-resistant acute severe ulcerative colitis (CONSTRUCT): a mixed methods, open-label, pragmatic randomised trial. Lancet Gastroenterol Hepatol. 2016;1(1):15-24. doi:10.1016/S2468-1253(16)30003-6

60. Croft A, Walsh A, Doecke J, Cooley R, Howlett M, Radford-Smith G. Outcomes of salvage therapy for steroid-refractory acute severe ulcerative colitis: ciclosporin vs. Infliximab. Aliment Pharmacol Ther. 2013;38(3):294-302. doi:10.1111/apt.12375

61. Rönnblom A, Holmström T, Tanghöj H, Karlbom U, Thörn M, Sjöberg D. Low colectomy rate five years after diagnosis of ulcerative colitis. Results from a prospective population-based cohort in Sweden (ICURE) diagnosed during 2005-2009. Scand J Gastroenterol. 2016;51(11):1339-1344. doi:10.1080/00365521.2016.1200141

62. Eriksson C, Cao Y, Rundquist S, et al. Changes in medical management and colectomy rates: a population-based cohort study on the epidemiology and natural history of ulcerative colitis in Örebro, Sweden, 1963-2010. Aliment Pharmacol Ther. 2017;46(8):748-757. doi:10.1111/apt.14268

63. Abou Khalil M, Boutros $\mathrm{M}$, Nedjar $\mathrm{H}$, et al. Incidence rates and predictors of colectomy for ulcerative colitis in the era of biologics: results from a provincial database. J Gastrointest Surg. 2018;22 (1):124-132. doi:10.1007/s11605-017-3530-y

64. Monterubbianesi R, Aratari A, Armuzzi A, et al. Italian Group for the study of Inflammatory Bowel Disease (IG-IBD). Infliximab three-dose induction regimen in severe corticosteroid-refractory ulcerative colitis: early and late outcome and predictors of colectomy. J Crohns Colitis. 2014;8(8):852-858. doi:10.1016/j.crohns.2014.01.006

65. Gibson DJ, Heetun ZS, Redmond CE, et al. An accelerated infliximab induction regimen reduces the need for early colectomy in patients with acute severe ulcerative colitis. Clin Gastroenterol Hepatol. 2015;13(2):330-335.e1. doi:10.1016/j.cgh.2014.07.041
66. Hindryckx P, Novak G, Vande Casteele N, et al. Review article: dose optimization of infliximab for acute severe ulcerative colitis. Aliment Pharmacol Ther. 2017;45(5):617-630. doi:10.1111/apt.13913

67. Nalagatla N, Falloon K, Tran G, et al. Effect of accelerated infliximab induction on short- and long-term outcomes of acute severe ulcerative colitis: a retrospective multicenter study and meta-analysis. Clin Gastroenterol Hepatol. 2018. pii: S1542-3565(18)30641-4. doi:10.1016/j.cgh.2018.06.031

68. De Cruz P Optimising Infliximab induction therapy for acute severe ulcerative colitis (PREDICT-UC). NCT02770040. Available from: https://clinicaltrials.gov/ct2/show/NCT02770040. Accessed December 15, 2018.

69. Rosen MJ, Minar P, Vinks AA. Review article: applying pharmacokinetics to optimize dosing of anti-TNF biologics in acute severe ulcerative colitis. Aliment Pharmacol Ther. 2015;41(11):1094-1103. doi:10.1111/apt.13175

70. Seow CH, Newman A, Irwin SP, Steinhart AH, Silverberg MS, Greenberg GR. Trough serum infliximab: predictive factor of clinical outcome for infliximab treatment in acute ulcerative colitis. Gut. 2010;59(1):49-54. doi:10.1136/gut.2009.183095

71. Brandse JF, van den Brink GR, Wildenberg ME, et al. Loss of infliximab into feces is associated with lack of response to therapy in patients with severe ulcerative colitis. Gastroenterology. 2015;149 (2):350-5.e2. doi:10.1053/j.gastro.2015.04.016

72. Ungar B, Mazor Y, Weisshof R, et al. Induction infliximab levels among patients with acute severe ulcerative colitis compared with patients with moderately severe ulcerative colitis. Aliment Pharmacol Ther. 2016;43(12):1293-1299. doi:10.1111/apt.13631

73. Gibson DJ, Hartery K, Doherty J, et al. CRP/Albumin Ratio: an early predictor of steroid responsiveness in acute severe ulcerative colitis. J Clin Gastroenterol. 2018;52(6):e48-e52. doi:10.1097/ MCG.0000000000000884

74. Choy MC, Seah D, Gorelik A, et al. Predicting response after infliximab salvage in acute severe ulcerative colitis. $J$ Gastroenterol Hepatol. 2018;33(7):1347-1352. doi:10.1111/jgh.14072

75. Farkas K, Rutka M, Golovics PA, et al. Efficacy of infliximab biosimilar CT-P13 induction therapy on mucosal healing in ulcerative colitis. J Crohns Colitis. 2016;10(11):1273-1278. doi:10.1093/eccojcc/jjw085

76. Kaniewska M, Moniuszko A, Rydzewska G. The efficacy and safety of the biosimilar product (Inflectra ${ }^{\circledR}$ ) compared to the reference drug (Remicade $\left.{ }^{\circledR}\right)$ in rescue therapy in adult patients with ulcerative colitis. Prz Gastroenterol. 2017;12(3):169-174. doi:10.5114/ pg.2017.70468

77. D’Ovidio V, Meo D, Viscido A, Bresci G, Vernia P, Caprilli R. Predictive factors of clinical response in steroid-refractory ulcerative colitis treated with granulocyte-monocyte apheresis. World J Gastroenterol. 2011;17 (14):1831-1835. doi:10.3748/wjg.v17.i14.1831

78. Dulai PS, Buckey JC Jr, Raffals LE, et al. Hyperbaric oxygen therapy is well tolerated and effective for ulcerative colitis patients hospitalized for moderate-severe flares: a phase $2 \mathrm{~A}$ pilot multi-center, randomized, double-blind, sham-controlled trial. $\mathrm{Am}$ $J$ Gastroenterol. 2018;113(10):1516-1523. doi:10.1038/s41395$018-0005-\mathrm{z}$

79. Yodoshi T, Hurt TL. Fecal microbiota transplantation to patients with refractory very early onset ulcerative colitis. Pediatr Gastroenterol Hepatol Nutr. 2018;21(4):355-360. doi:10.5223/ pghn.2018.21.4.355

80. Ochsenkühn T, Janelidze S, Tillack C, Beigel F. Ustekinumab as rescue treatment in therapy-refractory or -intolerant ulcerative colitis. J Crohns Colitis. 2018;12(suppl.1):P759. doi:10.1093/ecco-jcc /jjx121

81. Berinstein JA, Steiner CA, Regal RE, et al. Efficacy of induction therapy with high-intensity tofacitinib in 4 patients with acute severe ulcerative colitis. Clin Gastroenterol Hepatol. 2018. pii: S15423565(18)31265-5. doi:10.1016/j.cgh.2018.11.022 


\section{Publish your work in this journal}

Biologics: Targets and Therapy is an international, peer-reviewed journal focusing on the patho-physiological rationale for and clinical application of Biologic agents in the management of autoimmune diseases, cancers or other pathologies where a molecular target can be identified. This journal is indexed on PubMed Central, CAS, EMBase,
Scopus and the Elsevier Bibliographic databases. The manuscript management system is completely online and includes a very quick and fair peer-review system, which is all easy to use. Visit http://www.dovepress.com/testimonials.php to read real quotes from published authors.

Submit your manuscript here: https://www.dovepress.com/biologics-targets-and-therapy-journal 